DOI: https://doi.org/10.31874/2309-1606-2020-26-1-8

удК 37.013:327(438)

\title{
Sławomir Sztobryn
}

\section{Against the Tide.}

On the Pedagogy of Freedom in Polish Pedagogical Thought

Among the Eastern European countries in the

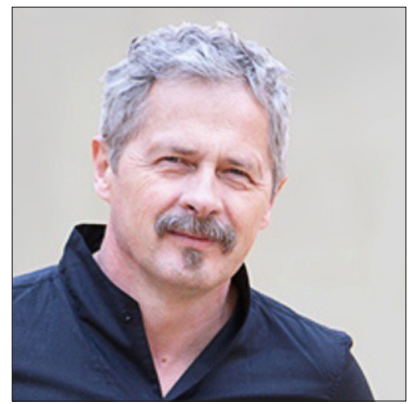
USSR's sphere of influence, Poland enjoyed the greatest freedom, which puts into question the hasty and evaluative assessments of the then educators, describing some of them as being homo sovietus or homo sovietus-like. The situation was very complex and it is in this perspective where one should undertake research on the past, 20th century pedagogical thought. Regardless of how ideologized Polish education was, it should be noted that many scholars who shaped their theoretical concepts in free, pre-war Poland opposed the promotion of Stalinism in science and education. At the time, the church played a certain positive role in this struggle, which also has to be recognized as a sham of opportunism. The pre-war philosophy of upbringing, particularly deviating from the doctrinal assumptions of Marxism-Leninism, became the main target of the attack, and such outstanding scholars as S. Hessen, B. Nawroczyński, L. Chmaj or K. Sośnicki were subject to harassment on the part of the authorities. The remnant of those times, which still lasts in the present day, is a belief in special value, and sometimes even in the foreground of empirical pedagogy with simultaneous negation of philosophical pedagogy. Meanwhile, it was Hessen who proved that empirical pedagogy - valuable in itself - is a great tool to learn how it is, but silent about how it should be. All teleology, which before the war grew out of philosophical currents (Hessen's neo-Kantism, Lviv-Warsaw school of Nawroczyński and Sośnicki) in the era of primacy of one party was a derivative of its ideology depriving pedagogy of its subjectivity and scientific autonomy. What makes Polish pedagogy of freedom different is the fact of practicing it in historical and philosophical orbit, when we look at it from the substantive side and positive disintegration, when we want to understand it from the personality of its creators.

Keywords: pedagogy, historical and philosophical pedagogy, pedagogy of freedom

The principal idea I would like to aim at is not so much to show how the (past and present) authorities appropriated education (it will be similar everywhere), but how Polish pedagogues with their theoretical concepts and attitude opposed the promotion of Stalinism in science and education. This can be an example of how to it is possible to fight against all claims of different forms of ideological monism that are also present today. I will refer to this group of educators and educational philosophers who, in the difficult years 
of Stalinism, continued their research either in the opposition to, or next to the trend called socialist education or socialist pedagogy. Next to them there appeared supporters of the new system. The biographies of these scholars clearly indicate not only those who the authorities promoted, but also those whom they destroyed in various ways. Political correctness, which characterizes a wide range of educators of those times, is a clear memento for equally politically correct or career-oriented contemporary educators. And there are still plenty of them.

The war period was extremely difficult both for Polish culture, and for Polish pedagogy. It brought great material and social losses; following German and Russian administration orders, the Polish intelligentsia was systematically and ruthlessly murdered both in the area of the present-day Poland and its borderlands. The end of the war did not change the situation to a large extent, because many Russians, as well as many Lithuanians, Belarusians, and Ukrainians, locked up in one camp called the USSR, still fought against the Polish intelligentsia in various ways. High politically-motivated sentences, numerous deportations to far-off lagers, political campaign of special services for the command and former Home Army soldiers - all this - when put together - was aimed at Polish culture, Polish intelligentsia, Polish tradition and Polish history. Open armed struggle, despite attempts being made, only brought casualties to people and cultural heritage. So the struggle which remained to be undertaken and continued was the one for the government of souls, for the possibility of smuggling certain ideals and contents by those who once lived in free Poland and survived the hematoma of war and then pseudo-liberation. It should be emphasized that in this struggle, also pretending to be a form of opportunism, a positive role was played by the Church; as the so-called People's power was not be able to annihilate it in a Soviet-like manner, at that time it turned out the Church had to protect the rudiments of Polishness. Today this mission seems to have already burned out.

So we have a special situation - on the one hand there are pedagogues, teachers of bourgeois provenance - as the party nomenclature spoke about them - continuing in their work the spiritual achievements of generations, and especially the extraordinary period of interwar Poland in our history; on the other hand, groups of politically correct careerists and party activists . Both groups had their representation at the universities, what was obviously visible in the obligatory literature and lectures ${ }^{1}$. A characteristic example of

\footnotetext{
${ }^{1}$ A good example of this was a textbook written by Godlewski, that is a reminiscent of a report on the PUWP congresses rather than the development of scientific pedagogy. This ideological burden is still on pedagogy, although this time other forces than the party are trying to annex it for themselves. The result is a one-faith religion at a Polish school. See: M. Godlewski, S. Krawcewicz, T. Wujek, Pedagogika, [Eng.: Pedagogy] Warsaw 1974. Until 1980, this textbook had six editions. The textbook by B. Suchodolski also had a similar character.
} 
a brilliant career thanks to the new power is the biography of Ignacy Szaniawski (1909-1983). A member of the Polish Workers 'Party and then the Polish United Workers' Party during the occupation in Lviv, he was an inspector at the Regional Department of People's Education and the author of pedagogical dissertations printed in Czerwony Sztandar [Eng.: Red Banner]. After the war, he became a lecturer at the University of Warsaw and the Military Political Academy, called by his co-workers a "belligerent Marxist" ${ }^{1}$ It was he who recognized B. Suchodolski's pre-war views as fascist, which - at that time - had the character of an unambiguous and dangerous stigmatization. However, this did not prevent him in the publication of joint source texts with Suchodolski and the second ideologist Wiktor Szczerba entitled Class and historical character of education ${ }^{2}$. The title itself clearly placed pedagogy as a discipline dependent on politics and enclosed in a circle of its needs. The pre-war philosophy of youth upbringing, particularly deviating from the assumptions of Marxism-Leninism, has become a subject of open criticism. However, it was never annihilated, not because of the weakness of power, but because of the strength of the scholars who cultivated it. If one looks at one of K. Kotłowski's dissertations, it clearly follows that the author, speaking of socialist pedagogy, mocked its victory, however, showed the undeniable merits of Hessen and Nawroczyński in the widely analyzed pedagogy of culture ${ }^{3}$. Writing about the impossibility of rejecting this pedagogy in the new socio-political reality, he justified it in the following way: "[...] representatives of this branch of pedagogy possessed the highest scientific culture and well-mastered methods of researching humanistic phenomena [...] their works, just like the lens, focus upon the almost all pedagogical achievements of humanity [...] Anyway, some of the suggestions contained in them for solutions to some pedagogical problems could be adopted on the basis of new pedagogy, such as the philosophical problem of determinism and indeterminism, which in pedagogy appears

\footnotetext{
${ }^{1}$ Cf. https://www.ipsb.nina.gov.pl/a/biografia/ignacy-szaniawski

${ }^{2}$ See: B. Suchodolski, I. Szaniawski, W. Szczerba, (1950) Klasowy i historyczny charakter wychowania. T1. Od wychowania $w$ ustroju wspólnoty pierwotnej do wychowania $w$ ustroju kapitalistycznym, [Eng.: Class and historical character of education. Vol.1. From education in the system of primary community to education in the capitalist system];. Volume 2 titled Klasowy i historyczny charakter wychowania. Wychowanie w ustroju socjalistycznym [Eng.: The Class and Historical Character of Education. Education in the socialist system] was published in 1951 and was developed independently by I. Szaniawski.

${ }^{3}$ K. Kotłowski, 1976, Pedagogika filozoficzna na Uniwersytecie Łódzkim w trzydziestoleciu Polski Ludowej [Eng.: Philosophical pedagogy at the University of Lodz in the thirtieth anniversary of Polish People's Republic], In: Acta Universitatis Lodziensis, Nauki HumanistycznoSpołeczne [Eng.: Acta Universitatis Lodziensis, Humanities and Social Sciences], series I, issue 14, pp. 119-134.
} 
most often as a matter of freedom and coercion in education ${ }^{1{ }^{\prime}}$ As one can see, not only is the defense of the so-called bourgeois pedagogy, but even the promotion of the most outstanding works from the interwar period. Of course, here is Spiritual Life by Nawroczyński and Freedom and coercion in education by the same author, and from Hessen's works Basics of pedagogy or On contradictions and unity of education. In all these works there appears a category of freedom; it is however, understood completely differently than in the practice of introducing Marxism in social life. Scholars of that time had to fake their Marxist orientation towards censorship, and at the same time skillfully smuggled into the public consciousness a system of values that had little to do with this orientation. We should also note that this very positive opinion about the scientific and methodological value of scholars of the interwar period was also a hidden criticism of the weakness of new academic staff carrying completely pauperized, not to say, primitive, pedagogy filled with the venom of ideology. Also, as a result of rejecting the philosophy of youth upbringing, the dominance of pedagogy and empirical psychology, of which Hessen wrote to be an excellent tool for learning "how it is", but completely unable to instruct about "how it is to be".

Freedom, perceived as a value - and for 120 years of non-state existence also as the goal of life for many generations of Poles - is in a way included in our genes. It is one of the most valued features. For other nations, with a different history and probably also a different mentality, an approach like this may seem strange, irrational or even odd. Polish patriotic education, service to the nation, readiness to sacrifice and fight were sucked out of mother's milk. However, it had a deep justification in literature and culture, which, despite numerous efforts of Germanization and Russification, penetrated into home education and to school (that was not Polish before 1918). This tradition of spiritual intensification has been with us since the 19th century, we know it from the works of both the poet Adam Mickiewicz ${ }^{2}$ and the philosopher Bronisław Trentowski ${ }^{3}$. The educational policy of the Austrian partition was perhaps the most liberal, which generally did not change the form the things were. It is with this luggage that we regained our freedom in 1918 but after

\footnotetext{
${ }^{1}$ Ibid. K. Kotłowski, p. 122.

${ }^{2}$ Compare the following remark one can find in A. Mickiewicz's Books of the Polish nation and Polish pilgrimage (Warsaw, 1986. p. 70): "You are not all equally good, but the worse of you is better than a good foreigner, because each of you has a spirit of sacrifice." This thought concerned the special role of Polish emigration in the fight for freedom. The cry for freedom (ours and yours) can also be found in MIckiewicz's The pilgrim's litany. Ibid, pp. 111-114;

${ }^{3}$ Trentowski, B.F., (1842), Chowanna czyli system pedagogiki narodowej jako umiejętności wychowania, nauki i oświaty, słowem wykształcenia naszej młodzieży [Eng.: Chowanna, or the system of national pedagogy as education, study and education skills, in a word, the education of our youth], Poznań : Księgarnia Nowa (1st Edition)
} 
20 years we were doomed to have our Thermopylae one more time. The history of Poland and Poles has left its mark on the system of values and the way they are experienced. Fighting was never our goal, but it became an imposed necessity. In such conditions, education was also observed to have contained this stigma; secret teaching, cultivated during the partitions, and developed again on an unprecedented scale during the Nazi occupation, involved many teachers and scholars after 1945. Almost all prominent Polish teachers took part in the academic secret teaching. As during the period of the Nazi and Russian occupation, scientific research was not abandoned, it naturally continued after the so-called liberation. After the war hecatomb, in which Polish intelligentsia was intentionally murdered, the first academic staff, were represented by a group of scholars who survived the war, the Warsaw Uprising, the entry of Soviet troops into Poland, and the Stalinization of the country. Each of these stages was occupied with blood. A large part of the Polish intelligentsia (pedagogy scholars included) were Polish Jews, whose extermination reached an unprecedented scale. The size of the Polish population was reduced by $17 \%$, similar losses were incurred only by Ukraine remaining within the borders of the USSR, and the largest losses were suffered by Belarusians (25\%). At the same time, Czechoslovakia lost around $2.4 \%$ of the population. In the post-war period, the scale of human losses and damage to educational infrastructure determined the possibilities and pace of enculturation. According to the Central Statistical Office, schools and scientific institutions in Poland lost $60 \%$ of their pre-war resources. One should also be aware that the theft of Polish material and spiritual property immediately after the end of the war by the Russians, that occurred on a scale comparable to war losses, has become another, great obstacle to the reconstruction of Polish culture. It is estimated that these losses reached about USD 50 billion. Getting up from a state of collapse not only required great fortitude, but also faith in the internal strength of our nation.

Writing about Polish education that remained within the orbit of Soviet influence, it is worth asking the question that concerned the basis of this implacable aggression on the one hand and heroic resistance on the other. Paradoxically, the answer to this question can be found in the documents of German military intelligence. Here are some statements from the high-ranking head of intelligence, General Reinchard Gehlen: On the pan-European resistance map, it is the Polish resistance that is leading and exemplary in many areas [...] $A$ Pole defends his independence against the Russians because they treat him as a western branch of Slavs, which is supposed to act as the front guard of Russian territorial claims ... Poles are threatened not only with the loss of independence of the state, but also with the melting of their national character in the East- 
ern melting pot. ${ }^{1}$ The Pole has a special talent for underground activity [...] the strength of the entire Polish resistance movement is the innate propensity of the entire nation to reside ${ }^{2}$. [...] Despite the most severe measures being taken by the police and the army, the German side was unable to limit or stop the avalanche of armed resistance, and its fight faces the greatest difficulties. This proves once again that the Polish resistance forces are so rooted in being a nation that their elimination by military and police means is out of the question ${ }^{3}$. One cannot underestimate the importance of these opinions spoken by the enemy. Certainly, Reinchard Gehlen was not a Polonophile, but - as an intelligence specialist - he was a good observer and had the ability to see what was hidden to others, which is the ability to assess the moral potential of the opponent. It is true that the fragments cited above concern the time of war, but for the Polish nation the broadly understood struggle did not end with the end of World War II; it only changed the forms, although there were also cases of armed struggle that took place in Poland in the 1960s. The new order introduced in the country was based on the elements of the power brought from the USSR and the leftist circles and ruthlessly imposed on us; it was the apparatus whose goals did not necessarily coincide with Stalin's aspirations and guidelines. Polish patriotism has had a tragic face for a long time. In the First World War, in both armies - German and Russian - Poles fought with one goal, which was the independence of their homeland. Suspended geopolitically between Scylla and Charybda, we - as a nation - have never lost the right direction, so boldly labeled Freedom. Soldiers died in the name of freedom in a fratricidal fight. This introduction seems necessary to me to better understand the lack of humility also among scholars and teachers who started their educational work in a new order.

Examples of the pedagogy of freedom can be found in many biographies of people of science, culture and education. This pedagogy was not just confined to literature, or thought, it was also expressed in their everyday attitude. First of all, it is necessary to mention intellectuals who did not cease their scientific activity and got involved in different forms of secret teaching during the turmoil of war. They will transfer the proven methods of education performed in tough conspiracy conditions up to the post-war period, thus building education, science and culture based on the outstanding achievements of the interwar generation. It was B. Nawroczyński who wrote his Spiritual Life during the occupation so as to publish it only after the war; others, like Hessen or Wąsik, lost their manuscripts and/or private libraries that abounded in white crows,

${ }^{1}$ Gehlen, R. (2016), Polskie podziemie w oczach wroga, [Eng.: Polish underground in the eyes of the enemy] Kraków : Wydawnictwo M, p. 16.

${ }^{2}$ Ibidem, p. 54;

${ }^{3}$ Ibidem p. 66 
and yet they recreated their work. Still others, like L. Chmaj or B. Skarga, returned to their homeland after many years spent in labor camps in the USSR and almost immediately began their scientific work, continuing and developing their pre-war ideas. Among them were those such as K. Kotłowski, who was imprisoned for their war activity in the Home Army, but started scientific work after being released. Instead of breaking them down, these traumatic experiences strengthened them. They retained their internal freedom despite external captivity. It is necessary to emphasize the regularity, unnoticeable at first glance, found in numerous biographies of many of the educators fighting for freedom by pen, word and attitude. They all practiced historical and philosophical pedagogy. And it was one of the victims of the new system. This was due to several reasons - first of all, the interwar period in Poland (but not only there) closed with the dominance of the pedagogy of culture over other sister currents, and this form of pedagogy was commonly recognized as being an important branch of - as we know it - philosophical pedagogy; secondly, everyone mentioned here had excellent philosophical education. For example, Wiktor Wąsik, being a historian of Polish philosophy, was also the author of the only (so far) work which included the history of the philosophy of education as its integral component; Kotarbiński, Nawroczyński, Sośnicki came from the famous Lviv-Warsaw School, whose originator was K. Twardowski; Hessen was a Neo-Kantist educated in Heidelberg; and K. Kotłowski was a doctor of pedagogy promoted by Hessen ${ }^{1}$. The fact of harassing these outstanding figures of Polish pedagogical and philosophical culture was not without significance for the relations of scholars with the constructors of the new system in Poland. In general, humanists were the most politically uncertain group of scientists ${ }^{2}$. Nawroczyński was prevented from contacting students for a long time, and forced to work as a librarian; Hessen, who was the co-founder of Łódź pedagogy, was subjected to the stalking of services that repeatedly invaded him at home, creating a constant sense of danger. The authorities' actions were also more "subtle". For example, Hessen was prevented from participating in the UNESCO deliberations, although only two Polish scholars received a personal invitation. The fate of Hessen's thoughts did not end with his death; until 1989, not a single monograph was devoted to him or his cultural pedagogy. Opportunists among educators - and this is not an individual phenomenon nowadays - were silent about it as if they were magic. The fear of the possible reactions effected by political authorities' was so great that my

\footnotetext{
${ }^{1}$ As part of subsequent conferences of the Society of Philosophical Pedagogy, we devoted indepth research to these scholars, which resulted in the multi-volume series of Philosophical Pedagogy. And there I would like to refer a reader who wants to find out the details of the biographies of these scholars.

${ }^{2}$ This, however, has not changed at all. All current political groups carrying populist slogans look awry at intelligence, and within it, humanists.
} 
doctoral dissertation, devoted entirely to Hessen, waited for a "better climate" for almost a year, and the monograph submitted by me to the widely read Polish-wide series Thoughts and People was never published there. Even in the 90s, Wincenty Okon ${ }^{1}$, the world-famous scholar and a doctor promoted by Hessen, while publishing his master's works in five volumes, did not resume the publication of Hessen's most important book from 1934 entitled Pedagogy and education in Soviet Russia ${ }^{2}$. Suddenly, after a change in the political situation in Poland, there grew out of the earth a multitude of experts on his educational philosophy. I do not question the substantive value of their work, but I am wondering about the collusion of silence, probably also the lack of intellectual courage, and - in rare cases - in recent times probably, also secret cooperation with the security service of the recent political authorities ${ }^{3}$.

It is possible to detect in Polish humanities a theory of positive disintegration, whose creator was Kazimierz Dąbrowski; the theory which - although being poorly pedagogically exploited - currently seems important to most humanities referring scholars. In Maria Syszkowska's (2014) opinion, the essence of the theory is the humanist's ability to overcome his/her own biological cycle and environmental pressure. What constitutes the individual is the ability of self-creation, which takes place in successive cycles of disintegration and secondary integration. In other words, positive maladjustment is valuable because it is the main driving force of man. Maladaptation has two dimensions: negative (alcoholism, drug addiction and crime) and positive. This second dimension means creative transformation of one's own effort. The social framework, especially power, is a limitation of this development and from this perspective, lack of adaptation is permissible ${ }^{4}$.

\footnotetext{
${ }^{1}$ W. Okoń, (1997) Dzieła wybrane (Eng. Selected works), Vol. 1: Fundamentals of pedagogy; Vol. 2: School and democracy at the turn; Vol. 3: On contradictions and unity of education; Vol 4: Structure and content of contemporary school; Vol. 5: Lesser letters, Warsaw. In the last volume W. Okoń recalled that until recently Hessen's biography could not appear in Polsce. Cf. ibid, p. 7.

${ }^{2}$ This book, published in Lviv, is difficult to access today, it can be found in 11 Polish libraries only. Similarly, no one undertook to publish one of the first works in the field of comparative pedagogy in which Soviet pedagogy looked pretty weak in comparison with Western pedagogy. Both books were written on the basis of a very broad source database, hence it is difficult to suspect the author of deliberately diminishing its value.

${ }^{3}$ To date, moreover, as it seems, this scientific community has not cleared itself of collaborators and other helpers of former secret police.

4 "Internal freedom is used by those who are capable of resistance and criticism towards the adaptation tendencies instilled in us." See: M. Szyszkowska, (2014) Wolność wewnętrzna I wolność zewnętrzna [Eng.: Internal freedom and external freedom], [in:] S. Sztobryn. K. Kamiński, (eds,) Wolność a wychowanie. Problemy, dylematy, kontrowersje [Eng.:Freedom and education. Problems, dilemmas, controversies], Łódź 2014, p. 16.
} 
Is the pedagogy of freedom just a theory? Of course not! It is expressed not only in words that sometimes come to humanists too easily. There is something Socratic about it, one needs great spiritual strength so as to integrate thoughts, words and deeds. Not everyone can afford it. Usually, such inner truthfulness of man results in his/her ostracism. The parad ox of modern times is that in some official speeches, some gold-speakers mention the category of [scientific] freedom among other contemporary "spells", but everyday reality shows their spiritual fineness expressed in harming others and in primitive blogs. What raises my respect for the philosophers of the education of postwar times is their strength to stick to the idea of the Truth against political opportunism and often even at the price of the so-called career. I have written so-called career, because I understand scientific work not as climbing up the social ladder, but as my unstoppable service to Science. Today, this completely unfashionable approach includes the notion of internal freedom as a necessary condition. Those who are able to behold themselves as constructors of their academic careers are - to some extent - slaves of their own weaknesses.

\section{References:}

Gehlen, R. (2016). Polskie podziemie w oczach wroga, [Eng.: Polish underground in the eyes of the enemy] Kraków : Wydawnictwo M;

Godlewski, M., \& Krawcewicz, S., \& Wujek, T. (1974) Pedagogika, [Eng.: Pedagogy], Warszawa; Retrieved from: https://www.ipsb.nina.gov.pl/a/biografia/ignacyszaniawski, accessed: 17/10/2019

Hessen, S. (1934). Pedagogika i szkolnictwo w Rosji Sowieckiej [Eng.: Pedagogy and education in Soviet Russia] , Lwów : Książnica Atlas. (Original edition: Education Policy in Soviet Russia, 1930, London : King and Son)

Kotłowski, K. (1976). Pedagogika filozoficzna na Uniwersytecie Łódzkim w trzydziestoleciu Polski Ludowej, [Eng.: Philosophical pedagogy at the University of Lodz in the thirtieth anniversary of People's Poland] In Acta Universitatis Lodziensis, Social and Humanist Sciences, series I, No 14.

Mickiewicz, A. (1986). Księgi narodu polskiego i pielgrzymstwa polskiego, [Eng.: Books of the Polish nation and Polish pilgrimage], Warszawa: Czytelnik;

Okoń, W. (1997). Dzieła wybrane [Eng.: Selected works), Warszawa: Wydawnictwo Żak;

Suchodolski, B., I. \& Szaniawski, I., \& Szczerba, W. (1950), Klasowy i historyczny charakter wychowania. T1. Od wychowania $w$ ustroju wspólnoty pierwotnej do wychowania $w$ ustroju kapitalistycznym, [Eng.: Class and historical character of education. Vol. 1. From education in the system of primitive community to education in the capitalist system] Warszawa : PZWS.

Szaniawski,I. (1951). Klasowy i historyczny charakter wychowania. Wychowanie w ustroju socjalistycznym, [Eng. : Class and historical character of education. Education in the socialist system] Warszawa : PZWS.

Sztobryn, S., \& Kamiński, K. (eds.) (2014). Wolność a wychowanie. Problemy, dylematy, kontrowersje [Eng.: Freedom and education. Problems, dilemmas, controversies], Łódź: Lodz University of Pedagogy Publishing House. 
Trentowski, B.F. (1842). Chowanna czyli system pedagogiki narodowej jako umiejętności wychowania, nauki i oświaty, słowem wykształcenia naszej młodzieży [Eng.: Chowanna, or the system of national pedagogy as education, study and education skills, in a word, the education of our youth], Poznań : Księgarnia Nowa ( $1^{\text {st }}$ Edition).

\section{Славомір Штобрин. Проти течії. Про педагогіку свободи у польській педагогічній думці}

Польща серед східноєвропейських країн, що знаходилися у сфері впливу СРСР, користувалася найбільшою свободою, що ставить під сумнів поспішні та оцінночні судження тодішніх освітян, називаючи деяких з них homo sovieticus. Ситуація була дуже складною, і в цьому контексті слід провести дослідження педагогічної думки XX століття. Незалежно від того, наскільки ідеологізованою була польська освіта, слід зазначити, що багато вчених, які формували свої теоретичні концепції у вільній, довоєнній Польщі, виступали проти пропаганди сталінізму в науці та освіті. У той час костьол відігравав певну позитивну роль у цій боротьбі, яка також вважалася опортуністичною. Передвоєнна філософія освіти, яка відійшла від доктринальних положень марксизму-ленінізму, стала головною мішенню нападу, і такі видатні вчені, як С. Гессен, Б. Наврочинський, Л. Чмай та К. Сосніцький, були предметом цькування з боку влади. Відгомін тих часів, який триває і донині, відображається у вірі в особливу цінність, а іноді й у виході на перший план емпіричної педагогіки з одночасним запереченням філософської педагогіки. Тим часом Гессен довів, що емпірична педагогіка - цінна сама по собі i $\epsilon$ чудовим інструментом для того, щоб дізнатися, як це $є$, але мовчати про те, як це має бути. Вся телеологія, яка до війни виросла з філософських течій (неокантіанство Гессена, Львівсько-Варшавська школа Наврочинського та Сосніцького) в епоху домінування однієї партії, була похідною від її ідеології, позбавляючи педагогіку її суб’єктивності та наукової самостійності. Польську педагогіку свободи вирізняє факт іi практичного розвитку в історико-філософській орбіті, коли ми дивимось на неі з предметної сторони та позитивного розпаду, коли ми хочемо зрозуміти iі через особистості ii творців.

Ключові слова: педагогіка, педагогіка свободи, польська філософія освіти, Гессен, Наврочинский, Сосніцький, емпірична педагогіка.

Славомир Штобрин. Против течения. 0 педагогике свободы в польской педагогической мысли

Польша среди восточно-европейских стран, находившихся в сфере влияния СССР, пользовалась наибольшей свободой, что ставит под сомнение поспешные и оценочные суждения тогдашних педагогов, называя некоторых из них homo sovieticus. Ситуация была очень сложной, и в этом контексте следует провести исследования педагогической мысли XX века. Независимо от того, насколько идеологизированной было польское образование, следует отметить, что многие ученые, формировавшие свои тео- 
Stawomir Sztobryn. Against the Tide. On the Pedagogy of Freedom in Polish Pedagogical...

ретические концепции в свободной, довоенной Польши, выступали против пропаганды сталинизма в науке и образовании. В то время костел играл определенную положительную роль в этой борьбе, которая также считалась оппортунистической. Довоенная философия образования отошла от доктринальных положений марксизма-ленинизма и стала главной мишенью нападок, а такие выдающиеся ученые, как С. Гессен, Б. Наврочинський, Л. Чмай и К. Сосницкий, были предметом травли со стороны властей. Эхо тех времен, докатившееся и до сегодняшнего дня, отражается в вере в особую ценность, а иногда и в выходе на первый план эмпирической педагогики с одновременным отрицанием философской педагогики. Между тем Гессен доказал, что эмпирическая педагогика - ценна сама по себе и является прекрасным инструментм для того, чтобы узнать, как это есть, но молчать о том, как это должно быть. Вся телеология, выросшая до войны из философских течений (неокантианство Гессена, Львовско-Варшавская школа Наврочинського и Сосницкого) в эпоху доминирования одной партии, была производной от ее идеологии, лишая педагогику ее субъективности и научной самостоятельности. Польскую педагогику свободы отличает факт ее практического развития в историко-философской орбите, когда мы смотрим на нее с предметной стороны и положительного распада, когда мы хотим понять ее через личности ее творцов.

Ключевые слова: педагогика, педагогика свободы, польская философия образования, Гессен, Наврочинский, Сосницкий, эмпирическая педагогика.

Славомір Штобрин, доктор габілітовний, професор кафедри педагогіки, Технічно-гуманітарна академія в Бєльсько-Бялій, Польща.

E-mail: s.sztobryn@wp.eu

https://orcid.org/0000-0003-3439-9200

Slawomir Sztobryn, Dr.dr hab., Professor of pedagogy department, University of Bielsko-Biale, Poland (Polish Akademia Techniczno-Humanistyczna w BielskuBiałej).

E-mail: s.sztobryn@wp.eu

https://orcid.org/0000-0003-3439-9200 